\title{
Developing a Model of Teaching Speaking through Discussion and Presentation for Accounting Education Students of UMS and IAIN Surakarta in 2014/2015 and 2015/2016 Academic Year
}

\author{
Sapta Mei Budiyanto \\ FKIP-English Education, Universitas Negeri Semarang, Kampus UNNES Bendan Ngisor Semarang, 50233, Central \\ Java, Indonesia \\ Mursid Saleh \\ FKIP-English Education, Universitas Negeri Semarang, Kampus UNNES Bendan Ngisor Semarang, 50233, Central \\ Java, Indonesia \\ Dwi Rukmini \\ FKIP-English Education, Universitas Negeri Semarang, Kampus UNNES Bendan Ngisor Semarang, 50233, Central \\ Java, Indonesia \\ Ahmad Sofwan \\ FKIP-English Education, Universitas Negeri Semarang, Kampus UNNES Bendan Ngisor Semarang, 50233, Central \\ Java, Indonesia
}

\begin{abstract}
The research aim is to develop a model of teaching speaking through discussion and presentation for teaching speaking for accounting education students. It is research and dvelopment study and the research was conducted and developed in three models. Each model consists of model draft planning, implementing the model, getting the model result and and revising the model. Technique of data collection was obtained by using test, interview, and observation; Technique of data analyzed for quantitative data used non independent t-test. He also used descriptive statistic including highest, average, and lowest scores. To analyze the qualitative data, the researcher used flow model of analysis. The research results showed that The first model: improved the students' bravery to speak up in front of the audience and made a better condition of the students' speaking environment. The second model results showed that the development of the students' speaking ability grew up rapidly and their grammar and vocabulary also getting better. The Final Model results showed that there is very clear and significant improvement on their bravery to speak up in front of the audience. Their learning progress grew up rapidly, their grammar and vocabulary also increased significantly. The computation result showed that all of the results is higher than $\mathrm{tt}(\mathbf{2 , 0 2})$. The hypothesis stating that developing a model of teaching speaking through presentation and discussion is good, suitable and accurate model for teaching and improving the Students' Speaking Ability of accounting education of UMS and IAIN Surakarta in 2015/2016 Academic Year was proved correct and significant.
\end{abstract}

Index Terms — developing, discussion, model, teaching, speaking, presentation, significant

\section{INTRODUCTION}

Everybody knows that English is the most important language in international communication nowadays. English is also the language of science and knowledge, because most of the science and knowledge in the world are written in English. Speaking is very crucial for education, business, economic and international communication, so that, the main target of someone study foreign language/English is the speaking ability. English is a means of international communication and the university students should learn how to speak English well, because their future, job, career, and education depended on it. Moreover, business and politics in international community in this modern era that has absolutely grown up rapidly with very tight and hard competition was demanded everyone to speak English well.We can understand the science and knowledge in the books, because we study and know about English. If we study hard, seriously and always practice it continuously and diligently, so we certainly can speak English well.Then, we can communicate with the foreign people smoothly and easily. 
Mohan raj said that "Twenty first century world is called a globalized village. Globalization is a great equalizer, at the same time it is a powerful divisive force. English is looked upon as a global language". Today, English is spoken by about 400 million native speakers; around 240 millions are Americans (Mohan raj J, 2013, p. 2). There are about 1500 millions who speak English as a second or foreign language. So, it is very important in international community. Crystal also stated that, "The notion of a generic native speaker has become so diversified that it has lost its meaning" and the environment in which other speakers of English as second language or foreign language learn English makes it very difficult to attain native like competence", so what is attainable and essential is intelligibility.

The students should be recognized that no matter what the department they come from, they should be able to speak English well. They have to study hard in order that be able to speak English well, because it is one of the most important capitals and requirements to compete in the crucial modern era for their better future. As everyone knows, that it is very tight and hard competition in international business, job, career, and education for getting a better and brighter future nowadays.

Most of people also realized that speaking is difficult enough to master, but the great effort should be done to achieve the best result that is "The ability to speak English well". Therefore, if students were able to speak English well, thus, they will get a better and brighter future for their job and career. It is absolutely true, that the ability of speaking English well, will give a lot of advantages and benefits for their job, life, career, business, education, and future, even this ability will be appreciated by other people and society.

Stepping from all of the statements above, the researcher wants to use and develop a model by using discussion and presentation for teaching speaking for accounting education. He regarded that the model will be accurate, suitable and appropriate for them, he believed that" By using discussion and presentation model will be able to overcome the students' speaking problems of accounting education.

\section{A. Reason of Choosing the Respondent}

The reasons why the reseacher choose accounting education as the respondents because they are diligent, smart, interesting and challenging, but their speaking English still poor, so it badly needed improvement.

\section{B. Reason of Choosing a Model}

The reasons why the researcher chooses discussion and presentation model for improving the students' speaking ability. He believed that if the accounting education students are taught and trained by accurate, appropriate and suitable model so they will be able to speak English well.

\section{Problems Identification}

a. The students have low spirit and motivation to study English

b. The environment' did not support the speaking practice

c. They felt ashamed, afraid, worried and nervous in speaking

d. The students have limited vocabularies and grammar.

\section{Problem Limitation}

a. The research and observation are conducted in UMS and IAIN Surakarta, especially for Accounting Education Students as a pilot project.

b. The researcher analyzes the elements which have closed relation with the object and problems of the research, those are; Developing, Model, Teaching, Speaking, Discussion, and Presentation.

\section{E. Research Questions}

1. What is the existing model of teaching speaking for accounting education students?

2. What kinds of model which is required for teaching speaking for them?

3. What is the most significant improvement on their speaking through discussion and presentation model?

4. How effective is the model of teaching speaking through discussion and presentation for them?

\section{F. Reseach Objectives}

The main targets of this dissertation research are;

1. To discover the existing model of teaching speaking for accounting education students.

2. To indicate that discussion and presentation model is suitable for teaching Speaking for accounting education sudents.

3. To discover the most significant improvement on the students' speaking ability through discussion and presentation model.

4. To measure the effectiveness of discussion and presentation model for teaching speaking for accounting education students.

\section{G. Significance of the Study}

There are three kinds of significance of this study;

\section{a. Theoretically}


We do hope that the product of this research and development study (Developing a Model of Teaching Speaking through Discussion and Presentation Techniques for AccountingEducation Students) would be beneficial and useful for teaching speaking for the accounting education students especially and non English department students in general. This model of teaching speaking could be adapted as the basis to develop the model and material for teaching speaking for adult students or university level.

\section{b. Pedagogically}

The research findings/results will be beneficial for language instruction to enlarge and enrich the model of teaching speaking for accounting education students especially and non English department students in general. The research findings gave the English lecturers many choices and alternativesfor increasing the accounting education students' speaking ability. The lecturers can use this model for teaching speaking easily and happily. It also helped the curriculum designers to plan the accurate and appropiate instructional program for teaching speaking for their own students' need. The textbook writer as well as the material developers can adopt this model in presenting the material, designing assignment and constructing exercise for the students.

\section{c. Practically}

The product of this research and development study can be used for teaching learning speaking in the classroom. This model of teaching speaking has proved suitable, appropiate and accurate to increase the accounting education students' speaking ability and hopefully can enhance and generate the speaking ability of the other non English department students in general.

From discussion the students get spirit and motivation to study speaking together with their friends, they helped each other to make summary of the topic discussion, this condition also supported them to practice their speaking. They also got a lot of new vocabulary, and better grammar from their discussion, because they discussed, the topic given by the lecturer in English.

From presentation, the students got bravery and self confidence to speak up in front of audience/class. It gave a lot of chances and opportunity for practicing and increasing their speaking ability. The students got the strongest spirit and motivation to study together in order not to feel ashamed, afraid, fear, worried and nervous anymore to express their ideas, feelings, and desires through speaking. Therefore, the members of the group supported each other to do the best one in speaking.

\section{H. The Assumption and Limitation of Development}

This research and development developed the model through discussion and presentation techniques to discover the best solution of the accounting education students' problems in expressing ideas, minds, desires, and feeling through speaking. The researcher recognized that this research is difficult and complect enough, therefore, he conducted this research and development carefully and seriously to find a good solution and alternatives for overcoming the students' speaking problem by using and implementing the model through discussion and presentation for teaching speaking for accounting education students in the classroom. He hoped that this research and development gave something valuable and useful for accounting education students to increase their speaking ability in general. He believed that the model generated and supported the development of students' speaking ability.

From the discussion and presentation, the researcher believed that the students would be accustomed to speak English, so that they could overcome their own problems in expressing ideas, desires, minds and feeling through speaking. The researcher gave them more convenience, interesting, lovely condition, situation and atmosphere to study English or speaking, so that, they got a good time and happiness in studying speaking/English; therefore, they increased and generated their own speaking ability. By doing so, the accounting education students have strong believed, spirit and motivation to study speaking/English, so that they could speak English well.

\section{REVIEW OF RELATED LITERATURE, FrAMEWORK OF THOUGHT AND HYPOTHESIS}

The research observes and analyzes the elements which have closed relation with the object and problems of the research, those are; Developing, Model, Teaching, Speaking, Discussion and Presentation.

\section{A. Developing}

To enlarge, to aid in the growth of strengthen, to improve the quality of, to cause to become more complex or intricate; add detailed and fullness, to bring into being gradually. To set forth or clarify by degrees. (Merriam Webster, 2013)

\section{B. Model}

Model is a schematic description of a system, theory, or phenomenon that accounts for its known or inferred properties and maybe used for futher study of its characteristics.

Model is a small object, usually built to scale, that represents in detail another, often large object. A representative form or pattern. (Margaret Rouse, 2011)

\section{Teaching}

Teaching is the act of profession of a person who teaches. Teaching is instruction, pedagogy is recognized as an 
important profession, precept, commandment, didactics, educational activity is (the activities of educating /instructing activities that impact knowledge or skill). Teaching is to cause to know something and to cause to know how, to cause to know the disagreeable consequeces of some action and to accustom to some action or attitude. It formed the performance, attitude and personality of the students to be better and wiser.

\section{Speaking}

Speaking means; By using language or communicating ideas, feeling, and desires by means of system of sound symbols or manners of using words. We know that speaking directly involves the use of words, so that by using words we can express our ideas, feelings, desires or even interest. In sociolinguistics, speaking model, is a model sociolinguistic study developed by Dell Hymes. To facilitate the application of his representation, Hymes constructed the acronym, S-P-E-A-K-I-N-G (for setting and scene, participants, ends, acts sequence, key, instrumentalis, norms, \& genre).

\section{E. Teaching Speaking}

It is very crucial and the main target of teaching speaking is how to make our students to be able to speak English well. Teaching speaking is to teach students to organize their thoughts in a meaningful and logical sequence. "Use language as a means of expressing values and judgments. Use the language quickly, confidently and as fluency as possible" (Nunan, 2003)

\section{F. Techniques for Teaching Speaking}

It is very important for the lecturers to understand techniques for teaching speaking, because better techniques will give better result. There are three kinds of techniques for teaching speaking, those are:

\section{a. Integrating English Vocabulary in Speaking}

Vocabulary is very crucial in speaking, if we got more vocabulary so our speaking ability would be better. There is no speaking without vocabulary. The lecturer can build the vocabulary of students through motivating activities. Some best practices for building listening and speaking vocabulary include: having short, targeted discussions about interesting themes, sharing images or objects that spark conversation.

\section{b. Integrating English Grammar in Speaking}

The mastering of good grammar is very important for speaking, so that the lecturer should teach good and correct grammar. By teaching good and correct grammar during speaking activities will make the students able to speak English well.

\section{c. Integrating English Pronunciation in Speaking}

Pronunciation and spelling has very important role to make speaking much more better than we hope and listening to fluent English in a variety of contexts is one of the best tools for teaching pronunciation.

\section{G. Discussion}

Discussion is to speak with another or others about; to examine or consider (a subject) in speech or writing. We make consideration of a subject by a group; an earnest conversation. it is essential that the purpose of the discussion activity is set by the lecturer, so we have to design assignments that are complicated and interesting and use those as springboards for discussion. There are three stages; 1 . Pre - Discussion/the forming group, 2. Discussion (the groups discuss the topic) 3. Post discussion (peer - feedback from the observer and lecturer).

\section{H. Presentation}

Most presentations are divided into 3 main parts (+ questions): 1 . In the introduction, we tell audience what the message is going to be. 2 . In the body, you tell audience the real message. 3 . In the conclusion, we summarize what the message was. Therefore, a successful presentation is one of the most effective ways of communicating your message.

\section{The Framework of Thought}

The researcher recognized that the English mastery of Accounting Education Students is still low and unsatisfying, so he needs a good, accurate and suitable model for teaching and improving the students' speaking ability. If the accounting education students are taught and trained by good, accurate and suitable model so they will be able to speak English well, therefore, presentation and discussion model is the best choice to do so.

\section{J. Hypothesis}

The hypothesis stated that: "Developing a Model of Teaching Speaking through Discussion and Presentation is a good, accurate and suitable model for teaching and improving the students' speaking ability of accounting education of UMS and IAIN Surakarta in 2015/2016 Academic Year."

\section{ReSEARCh Methodology}

\section{A. Model Development}

The Model Poduct Development consits of: Model Draft Planning, Implementing The Model, Getting The Model 
Result and and Revising The Model

A. Opening - $\mathbf{5}$ minutes
1. Brainstorming and Checking the attendance list of students
B. Discussion that involving one group $-\mathbf{2 0}$ minutes
1. Giving a topic for discussion that is in line with accounting students
2. Conducting discussion
C. Presentation - $\mathbf{3 5}$ minutes
1. Asking one group to present the result of discussion of a topic given
2. Delivering presentation of a topic'summary of discussion in front of class
3. Giving chance for audience by inviting questions, feedback, and suggestion.
4. Collecting questions, suggestion, and feedback from the whole class
5. Answering the questions, considering suggestion, listening feedback
D. Closing the meeting - 5 minutes
1. Drawing the conclusions of discussion and presentation.
2. Closing the meeting

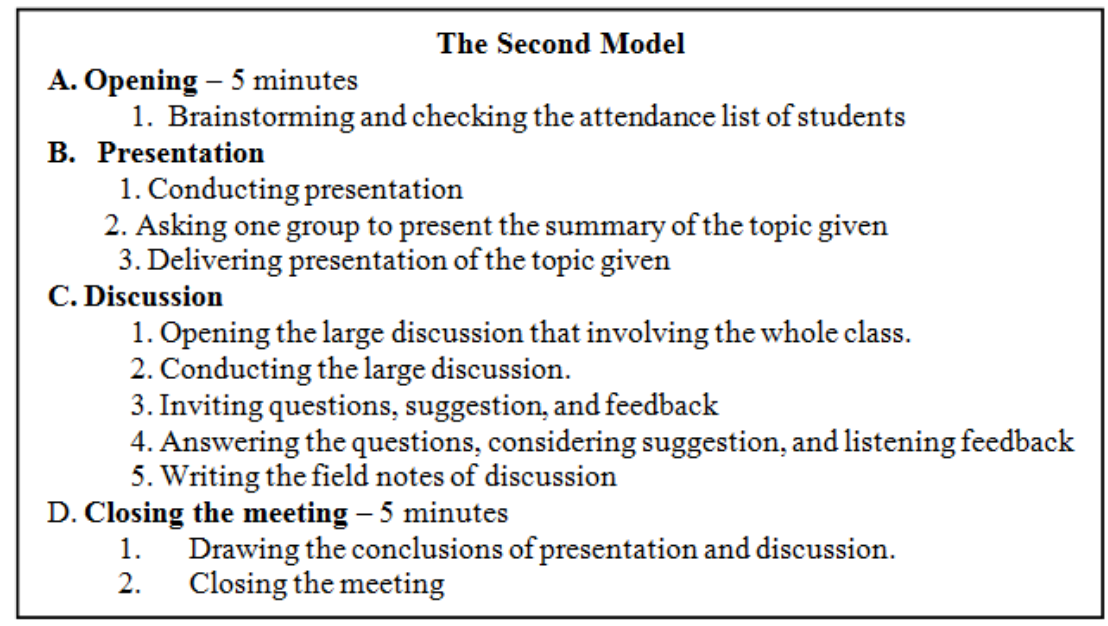

Ahe Final Model
A. Opening
1. Brainstorming and Checking the attendance list of students
B. Small discussion involving one group
1. Preparing the topics for discussion
2. Giving a topic for discussion (one topic one group)
3. Conducting a small discussion
C. Presentation
1. Conducting presentation
2. Asking one group to present the result of discussion of a topic given
3. Delivering presentation of a topic'summary of discussion
4. Opening a large discussion by involving all of students in a classroom
5. Drawing the conclusions of presentation.
D. large discussion among the groups and involving the whole class
1. Opening the large discussion that involving the whole class.
2. Conducting the large discussion by inviting questions, suggestion and feedback
3. Answering question, receiving or rejecting suggestion, and feedback.
4. Writing the field notes and Drawing the conclusion of discussion
E. Closing the meeting
1. Drawing the conclusions of presentation and discussion
2. Closing the meeting

\section{B. Method of Data Collection}

1. Interview for doing Need and Analysis: By conducting interview, he knew the students' condition and their problems,

2. Test: Researcher conducted pretest and posttest 1, 2 and 3.The main target of the test is to know whether there is a significant improvement or not on the students' speaking ability.

3. Observation: Reseacher and Collaborator observed what happened entirely and monitored the effect of the actions. 
It is done while he is taking actions and after he did it.

\section{RESEARCH RESULTS}

\section{A. The First Model Results}

The first model only solved a part of the students' speaking problems: Improving the students' bravery, spirit and motivation to study speaking and making a better condition of the students' speaking environment. Though, there are many students who made mistakes in grammar or vocabulary but it was okay. Eventhough the students' speaking ability was still low, but they are interested in the speaking lesson. The students are still having problems in speaking especially limited grammar, and vocabulary that still need improvement.

\section{B. The Second Model Results}

The second model results showed that the development of the students' speaking ability increased clearly. The researcher found significant improvement on their bravery and mentality to speak up in front of the audience.Their grammar and vocabulary also getting better. It improved the grammar and increased the vocabulary; it gave more opportunity for students to explore and express their minds, desires, feelings and ideas through speaking. It also gave special freedom for students to practice their speaking actively and happily.The researcher observed that the learning progress of the students' speaking ability improved rapidly and clearly. Their communication in English is also getting better and more fluently than before.

\section{The Final Model Results}

(Opening-Small Discussion-Presentation-Large Discussion-Closing)

The Final Model results showed that there are more significant improvements on the students' speaking ability. Their learning progress grows up rapidly and significantly. Their bravery, grammar and vocabulary are also increased and improved clearly. The results of the students' speaking ability were excellent and succeed. The Final Model increased and improved the students' speaking ability so clear and very significant, The Final model is also the most effective and efficient model to improve and increase the students' speaking ability. There is very sharp, clear and significant improvement on their speaking' ability after giving the treatment through this model and the best model to use for teaching speaking for accounting education students is also the final model. The most significant improvement in this research and development study is the students' fluency and bravery to speak up in front of the audience. The accounting education students will be able to speak English well, if they are trained and taught with accurate and suitable model.

\section{The Research Results from Discussion and Presentation}

\section{From Discussion,}

The students have learned a lot about how to work together and help each other, so that, no students feel lonely and sad, because the other students always care, ready to help their friends, when they got problem in speaking, grammar and vocabulary. From discussion, the students got spirit and motivation to study speaking together with their group. They support each other in studying speaking to increase vocabulary, improve grammar and discuss to make the summary of topic discussion given. The environment and condition also support them to practice their speaking English actively. The students also got spirit of togetherness for cherish and help each other, so that, they got experiences in discussing, sharing and solving their speaking problems from their own group. Discussion made the students accustomed to speak English and by discussing and studying together so they can overcome their own speaking problems.

\section{From Presentation,}

The students have learned about bravery and mentality to speak up in front of the audience/class, they have learned a lot about pronunciation, diction, fluency and courtesy in their speaking, and also listening of course. Because, when one of audience asked question and the group members answered their questions, so other students listened carefully and seriously about the answered, so that; they studied both of them speaking and listening altogether and automatically. When, there were many questions/feedback from audience/class that was curious of the topic, so, it made speaking class cheerful and lovely. The students got strong belief, bravery, mentality, spirit, and motivation to study speaking, so that, they did not feel ashamed,,afraid, and nervous anymore to express their ideas, feelings, and desires through speaking. The presentation gave a good training for the students to speak up in front of the audience/class, because by presenting the topic given by the lecturer, so, it gave more science, knowledge and experiences for practicing and increasing their speaking ability and their bravery.

\section{E. Computation Result}

The conclusion of the researcher was supported by the computation result:

a. The result between Pretest and Posttest 1 was 17, 80 because (17.8) is higher than tt (2.02), therefore, it can be concluded that there is significant improvement between pretest and Posttest 1

b. The result between Pretest and posttest 2 was $\mathbf{1 2 . 9 7}$ because (12.97) is higher than tt (2.02), therefore, it can be 
concluded that there is significant improvement between pretest and Posttest 2

c. The result between Posttest 1 and Posttest was $\mathbf{1 2 . 1 4}$ because (12.14) is higher than tt (2.02), therefore, it can be concluded that there is significant improvement between Posttest 1 and Posttest 2

d. The result between Pretest and Posttest 1 was $\mathbf{1 6 . 7 5}$ because (16.75) is higher than $t$ (2.02), therefore, it can be concluded that there is significant improvement between pretest and Posttest 1

e. The result between Pretest and Posttest 2 was $\mathbf{1 8 . 2 3}$ because (18.23) is higher than tt (2.02), therefore, it can be concluded that there is significant improvement between pretest and Posttest 2

f. The result between Posttest 1 and Posttest 2 was 7.50 because (7.50) is higher than tt (2.02) tt, therefore, it can be concluded that there is significant improvement between Posttest 1 and Posttest 2

\section{CONCLUSION}

1. The existing model of teaching speaking for accounting education mostly still using: drilling, repeat after me and pronunciation exercised. These kinds of models are difficult to improve the students' speaking ability.

2. Presentation and discussion model is the most required for teaching speaking for accounting education students, because it is good, accurate and suitable for them.

3. The most significant improvement is the students' fluency and bravery to speak up in front of the audience.

4. The most effective and the best model is the final model, because it is effective and efficient for teaching and improving the accounting education students' speaking ability.

5. The computation results supported the conclusion, because all of the results is higher than $t t(2,02)$.

The computation result showed that all of the result are higher than $t \mathrm{t}$ (2.02) thus, it can be concluded that there is significant improvement on the students' speaking ability after giving the model through discussion and presentation. The hypothesis stating that "Developing a Model of Teaching Speaking through Discussion and Presentation is a good, accurate and suitable model for teaching and increasing the students speaking ability of accounting education of UMS and IAIN Surakarta in 2015/2016 Academic Year" was proved correct and significant.

Suggestion

1.Trust our students, because every student has their own ability and potential. They have strength and weakness, so our duty is to explore their strength and to cover their weakness.

2 Give them more spirit, motivation, and bravery, so we will see their amazing ability, talent and potential to express their desire, feeling and opinion through speaking.

3. Set up our speaking classroom as interesting as possible, then provide with suitable and accurate topic and material that is in line with our students' need and discipline.

4. Keep remained our position as a good manager, motivator and facilitator, so that, we knew that our students actually are smart, creative, innovative and excellent human being.

\section{REFERENCES}

[1] Benjamins. Green, C. F. Christopher E. R., \& Lam J. (2002). Developing discussion skills in the ESL classroom In J. C. Richards \& W. A. Renandya (Eds.) Methodology in language teaching: An anthology of current practices (pp. 225-233) Cambridge: Cambridge University Press.

[2] Brown Douglas. (2001). TEACHING by PRINCIPLES an Interactive Approach to Language Pedagogy, Second Edition, San Francisco State University.

[3] Borg R Walter Gall Meredith and Joyce Gall. (2003). Educational Research; An Introduction, Seven Edition; Longman. University of Oregon. USA

[4] Benjamins. Boyer, S. (2003).Understanding spoken English: A focus on everyday language in context. Glenbrook, NSW: Boyer Educational Resources.

[5] Burns, A. (1998). Teaching speaking. Annual Review of Applied Linguistics, 18, 102-123. Cambridge University Press.

[6] Cobb, T. (2007). Computing the vocabulary demands of L2 reading. Language learning and Technology, 11 (3), 38-63.

[7] Coleman, H. (2011). Dreams and Realities: Developing Countries and the English Language. London, British Council

[8] Crystal, D. (2003). English as a Global Language. Cambridge, Cambridge University Press.

[9] Dornyei, Zoltan. (2005). Motivational Strategies in the Language Classroom Cambridge: Cambridge University Press.

[10] Grabe, W. (2010). Fluency in reading - Thirty-five years later, Reading in a Foreign Language, Volume 22 (1), pp. 71-83.

[11] Hall, G. (2013). This house believes that published course materials don't reflect the live sort needs of learners. English Language Teaching Global Blog. Oxford University Press Retrieved on 23 April 2013 at http://oupeltglobalblog.com/2013/04/05/this-house-believes-that-published-course-materials-dont-reflect-the-lives-or-needs-oflearners/

[12] Hinkle, E. (2006). Current perspectives on teaching the four skills. TESOL Quarterly, 40 (1) 109-131.

[13] Hymes, Dell. (1971). Competence and Performance in Linguistic Theory. London: Academic Press

[14] J. C. Richards \& W. A. Renandya. (Eds.), Methodology in language teaching: An anthology of current practices (pp. 225-233). Cambridge: Cambridge University Press.

[15] Joyce, B. Weil, M. \& Calhoun, E. (2011). Models of Teaching ( $8^{\text {th }}$ ed). Boston: Allyn Bacon/Pearson.

[16] Kinsinger, C. (2002). Defining the zone of proximal development in US foreign language education. Applied Linguistics, 23, $240-261$ 
[17] Ko. J., Schallert D. L., \& Walters, K. (2003). Rethinking scaffolding: Examining negotiation of meaning in an ESL story telling task TESOL Quarterly, 37, 303-324.

[18] Krashen, S.D. (2004). Free voluntary reading: New research, applications, and controversies. Paper presented at the 39th RELC International Seminar, 19-21 April, Singapore.

[19] Mohanraj, Professor. (2013). Teaching English in Today's World, English Education - The English and Foreign Languages University, Hyderabad 500007 (India) UNS TEFL International Conference.

[20] Lam, W., \& Wong, J. (2000). The effects of strategy training on developing discussion skills in an ESL classroom, ELT Journal, 54, 245-255

[21] Lantolf, J. P. (2000). Socio cultural theory and second language learning Oxford: Oxford University Press.

[22] McInerney, D.M., \&Liem, A.D. (2008). Motivation theory and engaged learning In P.A. Town drow, C. Koh, \& H.S. Tan (Eds.), Motivation and practice for the classroom (pp. 11-36). Rotterdam/Taipei: Sense Publishers.

[23] Machado, A. (2000). A Vygotskian approach to evaluation in foreign language learning contexts, ELT Journal, 54, 335-345.

[24] McCarthy, M. J. (2002). Good listenership made plain: British and American non-minimal response tokens in everyday conversation. In R. Reppen, S. Fitzmaurice \& D. Biber (Eds.), Using corpora to explore linguistic variation (pp. 49-71). Amsterdam:

[25] McCarthy, M. J. (2003). Talking back: 'Small' interactional response tokens in everyday conversation. Research on Language in Social Interaction, 36, 33- 63 Cambridge University Press

[26] Mori, J. (2002). Task design, plan, and development of talk-in-interaction: An analysis of a small group activity in a Japanese language classroom. Applied Linguistics, 23, 323-347.

[27] Nunan, David. (2004). Task-Based Language Teaching. New York: Cambridge University Press.

[28] Nassaji, H., \& Swain, M. (2000). A Vygotskian perspective on corrective feedback in L2: The effect of random versus negotiated help on the learning of English articles. Language Awareness, 9, 34-51.

[29] Payne, J. S., \& Whitney, P. J. (2002). Developing L2 oral proficiency through synchronous CMC: Output, working memory, and inter language development. CALICO Journal, 20, 7-32.

[30] Richards, Jack C. (2006). Communicative Language Teaching. New York: Cambridge University Press.

[31] Samuda, V. (2001). Guiding relationships between form and meaning during task performance: The role of the teacher. In M. Bygate, P. Skehan, \& M. Swain (Eds.), Researching pedagogic tasks: Second language learning, teaching and testing (pp. 119-140). Harlow, UK: Pearson.

[32] Shumin, K. (2002). Factors to consider: Developing adult EFL students' speaking abilities. In J. C. Richards \& W. A. Renandya (Eds.), Methodology in language teaching: An anthology of current practices (pp. 201-211). Cambridge: Cambridge University Press.

[33] Trent, J. (2009). Enhancing Oral Participation across the Curriculum: Some lessons from the EAP classroom, Asian EFL Journal, 11(1), 256-270

[34] Willy A Renandya. Current Belief in ELT and Its Implication in English Classrooms, May 18, 2013, National Institute of Education, Nanyang Technological University Singapore.

[35] Weir, C J. (1998). "Communicative Language Testing", Prentice-hall, International English Language Teaching, University of Reading, UK.

[36] Yuan, F., \& Ellis, R. (2003). The effects of pre-task planning and on-line planning on fluency, complexity and accuracy in L2 monologists oral production. Applied Linguistics, 24, 1-27.

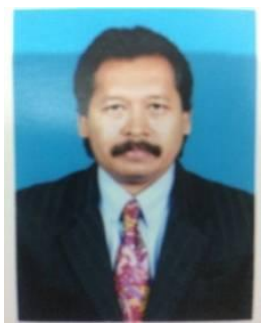

Sapta Mei Budiyanto was born at Surakarta/Solo/Mr. President' City, on May 27, 1964. He got S1 in 1990/UMS (Muhammadiyah University of Surakarta - English Education, His master/S2 in 2008/UNS (Surakarta State University) - English Education. Then His S3/Doctorate Program In 2017 - English Education. He is one of the lecturers at Muhammadiyah University of Surakarta (One of The Best Private Universities in Indonesia) since 1990 - Now at (FKIP/ LC UMS)

Mursid Saleh was born at Sleman, June 9, 1944. He got his Diploma at ELI, Victoria University of Wellington in 1973 Teaching English as Foreign Language, Undergraduate/S1 at IKIP Yogyakarta/1971 - English Education, then continued his master/S2 - Research Method in Education/1983 and Doctorate/S3 - Applied Linguistics at Macquarie University. He is one of the best lecturers at Graduate/Doctorate Program in UNNES

He is The Promotor of Sapta Mei Budiyanto at Doctorate program in UNNES.

Dwi Rukmini was born at Semarang, April 15, 1951. She got her bachelor at IKIP Negeri Semarang in 1974 - English Education and Diploma at Lancaster University - UK - English for Specific Purposes in 1984, Her S1 - Universitas Terbuka - English Education, Her master/S2 and Doctorate program/S3 at Universitas Negeri Semarang. She is one of the most familiar Lecturers at Graduate/Doctorate Program in UNNES.

She is The Co Promotor 1 of Sapta Mei Budiyanto at Doctorate program in UNNES. 
Ahmad Sofwan was born at Pemalang, April 27, 1962. He got his S1 at IKIP Yogjakarta in 1988, His Master/S2 at Deakin University in 1993 - Translation and La Trobe University in 1998- Linguistics. Then His Doctorate program/S3 at La Trobe University in 2004 - Linguistics. He is one of the most cooperative lecturers at Graduate/Doctorate Program in UNNES. He is The Co Promotor 2 of Sapta mei Budiyanto at Doctorate program in UNNES. 